\title{
COMMENTARY
}

\section{Insecurity in Kaduna: a collective failure and responsibility to protect}

\author{
Benjamin Maiangwa \\ Teaching Fellow in International Relations and Peace and Conflict Studies, \\ Durham University, England
}

Kaduna, a once glamorous and liberal capital city of Northern Nigeria is a state in ruins, judging by the crevices of its security issues. It has become a metaphor of thoughtless cruelty; with a host of kidnappers and marauders acting with impunity against defenceless civilians. The saga involving the gruesome kidnaping of 39 students from the Federal College of Forestry Mechanization in Afaka, is the most recent manifestation of this heinous crime that has gripped and shattered the social fabric of the state. Even the audacious release of the video showing the hapless students held at gunpoint and brutalized with a whip while screaming in pangs of pains in an unknown location that can only be likened to the depth of hades is a testament of our collective failure, and a clarion call for a collective responsibility to protect the lives of the innocent in Nigeria. The situation carries all the lineaments of Hobbes' state of nature, if there ever was one. The Afaka incident is just one of the many troubling signs of the despicable acts of inhumanity that vulnerable Nigerians have been thrown into in a time when the Covid-19 pandemic had exposed our socio-economic precarity.

This escalated phenomenon of kidnaping a preserve of the Niger Delta militants/emancipators and the so-called pirates in the Gulf of Guinea-is the 'new normal' now for most Nigerians. To be sure, Kaduna is no stranger to sectarian violence. It was part of my reality growing up in the state where I often woke up afraid of where the next gunshot would be fired, where screams of agony would be heard, and where kidnappers would pounce on their unsuspecting victims. The danger was always close to home. I have lost friends, classmates, and neighbours fleeing bloody internecine violence and crime for which Kaduna has become most (in)famous since the late 1980s.

Yet the issues were not always as menacing as they seem in the present clime. There were experiences of intense goodwill among the different groups alongside the malicious animosity 
that have accompanied my childhood in Kaduna. These encounters were revealing in our daily lives in schools, Churches, Madrassahs, and during our festivities when we shared food aplenty and prayed for the wellbeing of each other in spite and, even because of the troubles of the time. However, recent happenings have put a strain on this conviviality of our not-so-distant past with accusing fingers often pointed in the direction of the so-called "Fulani-herdsmen".

During my doctoral field research in southern Kaduna, I was struck by the absence of a large number of Fulani communities who, previously, had cohabited a considerable part of the area with the other ethnic groups. Most have fled to the Ladduga reserve area after the onset of the 2011 post-election violence. The crisis erupted as a result of President Muhammadu Buhari losing out to former President Good luck Jonathan at the polls. The disturbances and associated killings allegedly sponsored by Buhari's supporters, created further ethno-religious tensions and violence in the state. Consequently, some Fulani in southern Kaduna became subjects of counterattacks and fled to Ladduga. Some claims that others fled due to their involvement in crime and fear of retribution.

The Ladduga reserve area was created for pastoralists in the 1960s to provide better feeds to animals and curb the rivalries between mobile and settled groups over the use of land. Yet the area has generated intense debates over its ownership, pitting the Fulani and the other ethnic groups in fierce battle of ascendancy and relevance with each other. The other groups fear that the Fulani nurtures an intention to usurp the land in southern Kaduna and establish its dynasty. This perception is not helped by the slow or non-response of the government-which is perceived as advancing a 'Fulani agenda' -to the scourge of kidnapping and armed banditry in the country. It is partly as a result of this suspicion that many people rebuffed the idea by the federal government to establish cattle colonies or rural grazing settlements (RUGA) in the country. To them, the policy is reminiscent of the Fulani jihadist exploits in the 19th century.

As I moved about these deserted areas in southern Kaduna, I observed the empty spaces of vast land and houses that the Fulani families had abandoned and felt a sense of disharmony in the area. This disharmonious disposition shattered my idea and sense of home; home, conceived not merely as a physical site of abode, but a space and place of meaningful social and spiritual encounters between the people, and with the land. The sight of those uninhabited places and the conspicuous absence of Fulani women-adorned in their colourful attire-selling the natural and delicious fura (cereal) and nono (cow milk), felt like an immeasurable loss of some kind to me. The area lacked the familiarity, emotions, and aesthetics I once knew and fondly treasured. That idea of home has now become only a remembrance of a wistful time. 
Some of the people I interacted with expressed their views on what they felt had gone horribly wrong for them. Most acknowledged that the masterminds of these crimes are their elite who not only instigate violence through careless rhetoric and partisan politicking but also allow the crimes to fester; for in doing so, many believe that these politicians could reap the bounty of war! Then there are the guttersnipes who cash in on the festering wound in the polity for their own selfish gains, often sacrificing human lives on the altar of greed and punitive justice. Altogether, the people related the impunity of the criminals to political partisanship and ethno-religious sentiments, economic exploitation, government's perceived or real negligence to prosecute perpetrators of violence, and the loss of cattle herd and pasture lands. Other issues include the 1804 jihad, British divide-and-rule or "define-and-rule" tactic, and hydra-headed religiosity that came hard on the heels of Nigeria's return to a democratic rule in 1999. Moreover, years of negligence of human needs and suppression of the rights of people to emancipate themselves from the imperviousness of subversive regimes wound up creating a feeling of detachment from the state. This feeling has accelerated the physical and psychological rift between the groups, locking them into their segregated enclaves.

If this much makes sense, then to usefully grasp the intricacies of intergroup relations and crime in Kaduna, we must look beyond the essentialist explanations that proliferate the media and everyday discourses which paint different identities as incurably evil or violent-prone. Evidence of symbiotic relationships created and sustained over the years between the different groups proves that without the additional reification of cultural identities and socio-political realities, the "usthem" thinking does not always implicate groups in violence, nor does it justify it. Indeed, a society can be expected to change its system of perceptions when it bothers on its security, livelihood, and the survival of its cultures and people.

There is a need for the groups to harness their material and immaterial resources to create a sense of belonging and security within a single political community where diversity is upheld with dignity. To achieve this, they must first unlearn the misplaced idea that they are intransigent enemies with incompatible interests. Their socio-economic and political conditions have not fared any better by feeding off of this idea. They will have to carve out spaces for themselves to negotiate the terms of their continued coexistence in light of their changing cultural norms, socioeconomic needs, and demography. Such critical engagements through negotiation of space, power, and resources could, potentially, loosen the extremities of the groups and set the tone for the transformation of Kaduna to the home I once knew, or an even better place. 